\title{
In Search of Spring
}

Elizabeth Cruickshank

Finding footprints of the Horned Larks' three toes and long hind claw, made us impatient to see them and any other heralds of spring. A drive to the Qu'Appelle Valley gave us a close view of several flocks travelling in company with their near relatives, the Snow Buntings. Watching the gay frolicking play of the Snowbirds with their tinkling bell-like song, we felt that they too were glad to welcome back the first of our spring birds. On a fence post, as though intrigued by the actions of the swirling, wheeling, happy little feathered folk in the field, perched an immaculate, large Snowy Owl.

Starlings were enjoying the sunlight on topmost branches of the cottonwoods in the farmyard-the polished sheen of their plumage reflecting the light. A flash of rose led us to the maple trees, where Pine Grosbeaks were feeding on the maple seeds and dried chokecherries and haws near them. As we watched them, Downy and Hairy Woodpeckers visited the feedingtray for their daily rations of suet and crumbs which they shared with their jolly little feathered acrobats, the Chickadees. A Red Squirrel hurried past us towards the river, where they have been numerous this winter.

Through deep snow we walked over the hill to the wooded ravine. Footprints of all sizes led to the sheltered spot. We could not distinguish the tracks as they crossed and recrossed, some in circles, some in straight lines. Tunnel-like trails we did not understand-nor the very tiny exclamation marks. Little mouse-coloured animals, less than two inches long, with short tails, had been picked up dead on the road. Could the marks belong to them, we wondered.

Entering the ravine was like opening a door into fairyland. Calm enveloped us in this silent sanctuary-so lately one of mellow fruitlessness. The frost laden branches formed a tapestry of silver; dark red haws on thorny branches looked unreal, lending enchantment to the moment.

I thought now I know "how silence sings" when my little companion's voice startled me. "Will the blue violets grow here again, Gram?". Having known only four summers, how could she be sure?

What a fitting place to interpret to the child the glory of resurrection! How the silver weed would again form a golden studded carpet; the essence were reluctant to leave the valley with its glorious panorama. But we knew little suns in the shrinking pool.

Suddenly from deep in the sheltered quiet came a fragment of song! (Three robins were known to have wintered in the valley).

The sun had lifted the blanket of mist that had lain on the hills. We werereluctant to leave the valley with its glorious panorama. But we knew it would not be long before the air would be "sweet with the flutes of the Meadowlarks".

We had not found spring, but we had seen messengers who proclaim its approach. 